\title{
Simultaneous determination of methocarbamol and ibuprofen or diclofenac potassium using mean centering of the ratio spectra method
}

\author{
NOURUDDIN WAGEIH ALI ${ }^{1 *}$ \\ MAHA AHAMD HEGAZY² \\ MOHAMED ABDELKAWY2 \\ EGLAL ABDELAHAMID ABDELALEEM ${ }^{1}$ \\ 1 Pharmaceutical Analytical Chemistry \\ Department, Faculty of Pharmacy \\ Beni-Suef University, Beni-Suef, Egypt \\ 2 Pharmaceutical Analytical Chemistry \\ Department, Faculty of Pharmacy, Cairo \\ University, Cairo, Egypt
}

\begin{abstract}
Accurate and sensitive methods were developed for simultaneous determination of methocarbamol and ibuprofen or diclofenac potassium in their binary mixtures, and in the presence of a methocarbamol related substance (guaifenesin) using mean centering of the ratio spectra method. The results obtained were statistically compared with the reported HPLC methods; no significant difference between the proposed methods and the reported methods was found regarding either accuracy or precision.
\end{abstract}

Keywords: methocarbamol, diclofenac potassium, ibuprofen, mean centering of ratio spectra, guaifenesin

Methocarbamol (ME), 2-hydroxy-3-(2-methoxyphenoxy) propyl carbamate (Fig. 1a), is a centrally acting skeletal muscle relaxant whose action may be due to its general depressant effects on the CNS. It is used as an adjunct in the short-term symptomatic treatment of painful muscle spasms associated with musculoskeletal conditions and is sometimes given with analgesics for musculoskeletal pain treatment $(1,2)$. Ibuprofen (IB), 2-(4-isobutylphenyl) propionic acid (Fig. 1b), and diclofenac potassium (DI), potassium [o-(2,6-dichloroanilino)phenyl] acetate (Fig. 1c), are non-steroidal drugs with anti-inflammatory, antipyretic and analgesic properties (1). ME formulated with either IB or DI is frequently prescribed to alleviate pain associated with muscle spasm. Guaifenesin (GU), 3-(2-methoxyphenoxy)-propane-1,2-diol (Fig. 1d), is considered as a substance related to ME (1). Moreover, GU may be produced by ME hydrolysis, especially in alkaline medium, and hence it is also considered to be the main degradation product of ME (2).

\footnotetext{
* Correspondence; e-mail: dr.nourali@hotmail.com
} 
<smiles>NC(=O)OCC(O)COc1ccccc1O</smiles>

b)<smiles>CC(C)Cc1ccc(C(C)C(=O)O)cc1</smiles><smiles>O=C(O)Cc1ccccc1Nc1c(Cl)cccc1Cl</smiles>

Fig 1. Chemical structure of: a) methocarbamol, b) ibuprofen, c) diclofenac potassium.

There are many reports on the determination of ME, IB, DI and GU separately or in combination with other drugs. Only a few methods have been reported for determination of either ME and IB or ME and DI in binary mixtures (3-12). Only one method has been reported for determination of ME and DI in the presence of GU (13). This is an HPLC method that uses gradient elution and different wavelengths.

Non of the reported spectrophotometric methods can be applied for simultaneous determination of binary mixtures of ME and IB. No methods have been reported for determination of $\mathrm{ME}$ and IB in the presence of GU.

Therefore, the objective of this work was to develop, simple, a sensitive and selective method for the determination of $\mathrm{ME}$ and its related substance GU in ternary mixtures with IB and DI. This is the first report on the determination of ME and IB in the presence of GU.

\section{EXPERIMENTAL}

\section{Standard samples and reagents}

Standard ME and DI with certified purity of 99.80 and $99.97 \%$, respectively, were kindly supplied by October Pharma S.A.E., Egypt. Standard IB with certified purity of $100.06 \%$ was kindly supplied by El Kahira Co., Cairo, Egypt. Standard GU with certified purity of $99.95 \%$ was kindly supplied by RAMEDA Co., Egypt.

All other reagents and chemicals used were of analytical grade and were used without further purification. Methanol HPLC grade was from SDS, France.

\section{Pharmaceutical formulations}

Ibuflex ${ }^{\circledR}$ tablets were manufactured by Global Napi Pharmaceuticals. Each tablet is claimed to contain $750 \mathrm{mg}$ of ME and $400 \mathrm{mg}$ of IB. Dimra ${ }^{\circledR}$ tablets were manufactured by October Pharma S.A.E., Egypt. Each tablet is claimed to contain $500 \mathrm{mg}$ of ME and 50 $\mathrm{mg}$ of DI. 
N. Wageih Ali et al:: Simultaneous determination of methocarbamol and ibuprofen or diclofenac potassium using mean centering of the ratio spectra method, Acta Pharm. 62 (2012) 191-200.

\section{Instruments and conditions}

A double beam UV-Visible spectrophotometer (Shimadzu, Japan) model UV-1601 PC with a quartz cell of $1 \mathrm{~cm}$ pathlength, connected to an IBM compatible computer, was used. The software was UVPC personal spectroscopy software version 3.7. All computations were performed in Matlab for Windows ${ }^{\mathrm{TM}}$ version 6.5 .

For HPLC analyses $(3,4)$, an HPLC (Shimadzu) instrument equipped with a model series LC-10 ADVP pump, SCL-10 AVP controller, DGU-12 A degasser and SPD-10 AVP UV-VIS detector was used. Separation and quantitation were made on a $250 \times 4.6 \mathrm{~mm}$ (i.d.) RP C18 column (4.6 $\mu \mathrm{m}$ particle size).

\section{Standard solutions}

Stock solutions for each of ME, IB and DI $\left(1 \mathrm{mg} \mathrm{mL}^{-1}\right)$ were prepared by dissolving pure powder in methanol. The latter were diluted to $10 \mu \mathrm{g} \mathrm{mL}^{-1}$ with $0.1 \mathrm{~mol} \mathrm{~L}^{-1} \mathrm{HCl}$.

Each stock solution of ME, IB and DI was separately diluted ten times with methanol to get a $100 \mu \mathrm{g} \mathrm{mL}^{-1}$ working solution of each of them.

\section{Analytical procedures}

The absorption spectra of $10 \mu \mathrm{g} \mathrm{mL}-1$ of each of ME, DI, IB and GU in $0.1 \mathrm{~mol} \mathrm{~L}^{-1}$ $\mathrm{HCl}$ were recorded over the range $200-400 \mathrm{~nm}$ using $0.1 \mathrm{~mol} \mathrm{~L}^{-1} \mathrm{HCl}$ as blank.

Linearity and calibration curves. - Aliquots equivalent to 40-200 $\mu \mathrm{g}$ ME and 40-220 $\mu \mathrm{g}$ IB were transferred from their working standard solutions $\left(100 \mu \mathrm{g} \mathrm{mL}^{-1}\right)$ into two series of $10-\mathrm{mL}$ volumetric flasks, the volume was made up to the mark with $0.1 \mathrm{~mol} \mathrm{~L}^{-1} \mathrm{HCl}$ to obtain final concentration solutions of $4-20 \mu \mathrm{g} \mathrm{mL}^{-1}$ for ME and 4-22 $\mu \mathrm{g} \mathrm{mL}^{-1}$ for IB. Absorption spectra of the resulting solutions were measured in the range of $210-240 \mathrm{~nm}$. Scanned spectra of ME were divided by the absorption spectrum of $4 \mu \mathrm{g} \mathrm{mL} \mathrm{m}^{-1}$ of IB; the same was applied to the spectra of IB divided by $4 \mu \mathrm{g} \mathrm{mL} \mathrm{mL}^{-1} \mathrm{ME}$ spectrum and the obtained ratio spectra were mean centered for $\mathrm{ME}$ and IB mixture. The mean centered values at $218.4 \mathrm{~nm}$ for both ME and IB were recorded and plotted $v s$. the corresponding concentrations. Regression equations were then computed.

Aliquots from working standard solutions $(100 \mu \mathrm{g} \mathrm{mL}-1)$ equivalent to $40-200 \mu \mathrm{g}$ ME and 30-120 $\mu \mathrm{g}$ DI were also transferred into two series of 10-mL volumetric flasks and the volume was made up with $0.1 \mathrm{~mol} \mathrm{~L}^{-1} \mathrm{HCl}$ to get final solutions of $4-20 \mu \mathrm{g} \mathrm{mL}^{-1}$ for $\mathrm{ME}$ and 3-12 $\mu \mathrm{g} \mathrm{mL}^{-1}$ for DI. Absorption spectra of the resulting solutions were measured in the range of 220-285 $\mathrm{nm}$. Scanned spectra of ME were divided by the absorption spectrum of $6 \mu \mathrm{g} \mathrm{mL} \mathrm{mL}^{-1}$ of DI while the spectra of DI were divided by the absorption spectrum of $18 \mu \mathrm{g} \mathrm{mL}^{-1}$ of $\mathrm{ME}$ and the obtained ratio spectra were mean centered. The mean centered values at 279.4 and $260.6 \mathrm{~nm}$ for ME and at $260.8 \mathrm{~nm}$ for DI were plotted $v s$. the corresponding concentrations, and regression equations were computed.

Analysis of laboratory prepared mixtures. - Different mixtures containing ME and IB or DI in different ratios were prepared. The procedure for each mixture was followed as mentioned above. Concentrations of ME, IB, DI and GU were calculated by the corresponding regression equation. 
N. Wageih Ali et al.: Simultaneous determination of methocarbamol and ibuprofen or diclofenac potassium using mean centering of the ratio spectra method, Acta Pharm. 62 (2012) 191-200.

Application to pharmaceutical preparations. - Ten tablets of Ibuflex ${ }^{\circledR}$ were accurately weighed, then thoroughly powdered and mixed. An accurate weight of mixed powder equivalent to $750 \mathrm{mg}$ of ME and $400 \mathrm{mg}$ of IB was transferred into a 250-mL beaker, 50 $\mathrm{mL}$ methanol were added and stirred magnetically for 10 minutes. The solution was filtered into a 100-mL volumetric flask, and the volume was made up with methanol to obtain a stock solution of concentration equivalent to 7.5 and $4 \mathrm{mg} \mathrm{mL}^{-1}$ of $\mathrm{ME}$ and IB, respectively. Appropriate tenfold dilution of this stock solution was made to prepare a solution equivalent to 75 and $40 \mu \mathrm{g} \mathrm{mL}^{-1}$ of $\mathrm{ME}$ and IB, respectively. The procedure detailed under linearity and construction of the calibration curve for each mixture was followed as mentioned above. Concentrations of ME and IB were calculated by the corresponding regression equation.
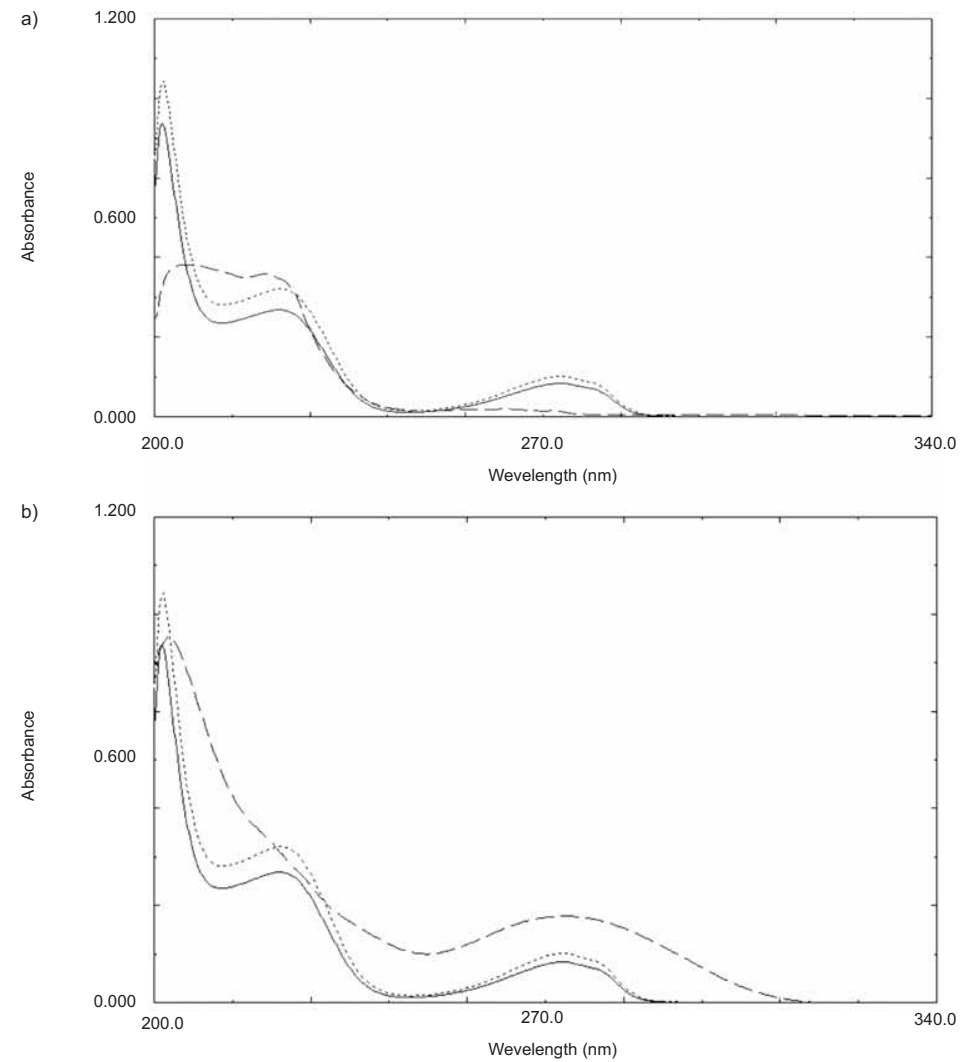

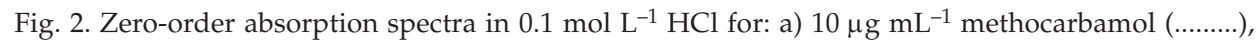

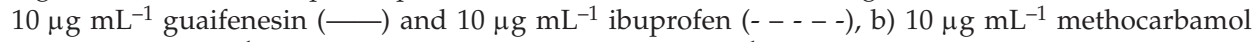
(.........), $10 \mu \mathrm{g} \mathrm{mL} \mathrm{m}^{-1}$ guaifenesin ) and $10 \mu \mathrm{g} \mathrm{mL}^{-1}$ diclofenac potassium (- - - -). 
N. Wageih Ali et al:: Simultaneous determination of methocarbamol and ibuprofen or diclofenac potassium using mean centering of the ratio spectra method, Acta Pharm. 62 (2012) 191-200.

Table I. Regression parameters of the proposed MCR methods for determination of ME with IB or DI

\begin{tabular}{lccccc}
\hline Parameter & Methocarbamol & Ibuprofen & Methocarbamol & $\begin{array}{c}\text { Diclofenac } \\
\text { potassium }\end{array}$ \\
\hline$\lambda(\mathrm{nm})$ & 218.4 & 218.4 & 260.6 & 279.4 & 260.8 \\
$\begin{array}{l}\text { Calibration range } \\
\left.(\mu \mathrm{g} \mathrm{mL})^{-1}\right)\end{array}$ & $4-20$ & $4-22$ & $4-20$ & $4-20$ & $3-12$ \\
Model accuracy & $100.0 \pm 0.9$ & $100.0 \pm 1.6$ & $100.0 \pm 1.6$ & $100.2 \pm 1.7$ & $100.0 \pm 1.0$ \\
$L O D / L O Q ~\left(\mu g \mathrm{~mL}^{-1}\right)$ & $1.5 / 3.5$ & $1.5 / 3.5$ & $1.5 / 3$ & $1.5 / 3$ & $1.0 / 2$ \\
Intra-day RSD $(\%)$ & 0.9 & 0.9 & 0.9 & 0.9 & 0.9 \\
Inter-day RSD $(\%)$ & 1.2 & 1.8 & 1.1 & 1.1 & 1.0 \\
\hline
\end{tabular}

As for Ibuflex ${ }^{\circledR}$ tablets, an appropriate dilution of stock solution was made to prepare a solution equivalent to 75 and $40 \mu \mathrm{g} \mathrm{mL}^{-1}$ of $\mathrm{ME}$ and $\mathrm{DI}$, respectively.

\section{RESULTS AND DISCUSSION}

The focus of this work was to develop simple, sensitive and accurate analytical methods for simultaneous determination of ME and IB or DI in their binary mixtures. Mean centering of the ratio spectra method (MCR, 14) was applied for simultaneous determination of the studied binary mixtures without prior separation steps. MCR method has the advantage of eliminating the derivative steps and therefore the signal-to-noise ratio is not degraded.

\section{Method development and optimization}

The zero-order absorption spectra of ME and IB or ME and DI mixtures show severe overlapping (Figs. 2a,b), which did not allow us to use direct spectrophotometric measurements for simultaneous determination of ME and IB or DI.

The effect of divisor concentration on the analytical parameters such as slope, intercept and correlation coefficient was also tested. For the first mixture, $4 \mu \mathrm{g} \mathrm{mL}^{-1}$ of IB and $\mathrm{ME}$ was used as a divisor for determination of both ME and IB at $218.4 \mathrm{~nm}$. For the the second mixture $6 \mu \mathrm{g} \mathrm{mL}-1$ of DI was used as a divisor for determination of ME at 260.6 $\mathrm{nm}$ and $279.4 \mathrm{~nm}$ while $18 \mu \mathrm{g} \mathrm{mL}^{-1}$ of ME was used as a divisor for determination of DI at $260.8 \mathrm{~nm}$. The chosen divisior concentrations gave good results for the slope, intercept and correlation coefficient of calibration graphs as well as for selectivity.

\section{Method validation}

Method validation was performed according to ICH the guidelines (15) for proposed methods.

Linearity of the proposed methods was evaluated and it was evident in the range of 4-20 $\mu \mathrm{g} \mathrm{mL}^{-1}, 4-22 \mu \mathrm{g} \mathrm{mL}-1$ for ME and IB, respectively, in the first mixture and 4-20 $\mu \mathrm{g}$ 
N. Wageih Ali et al:: Simultaneous determination of methocarbamol and ibuprofen or diclofenac potassium using mean centering of the ratio spectra method, Acta Pharm. 62 (2012) 191-200.
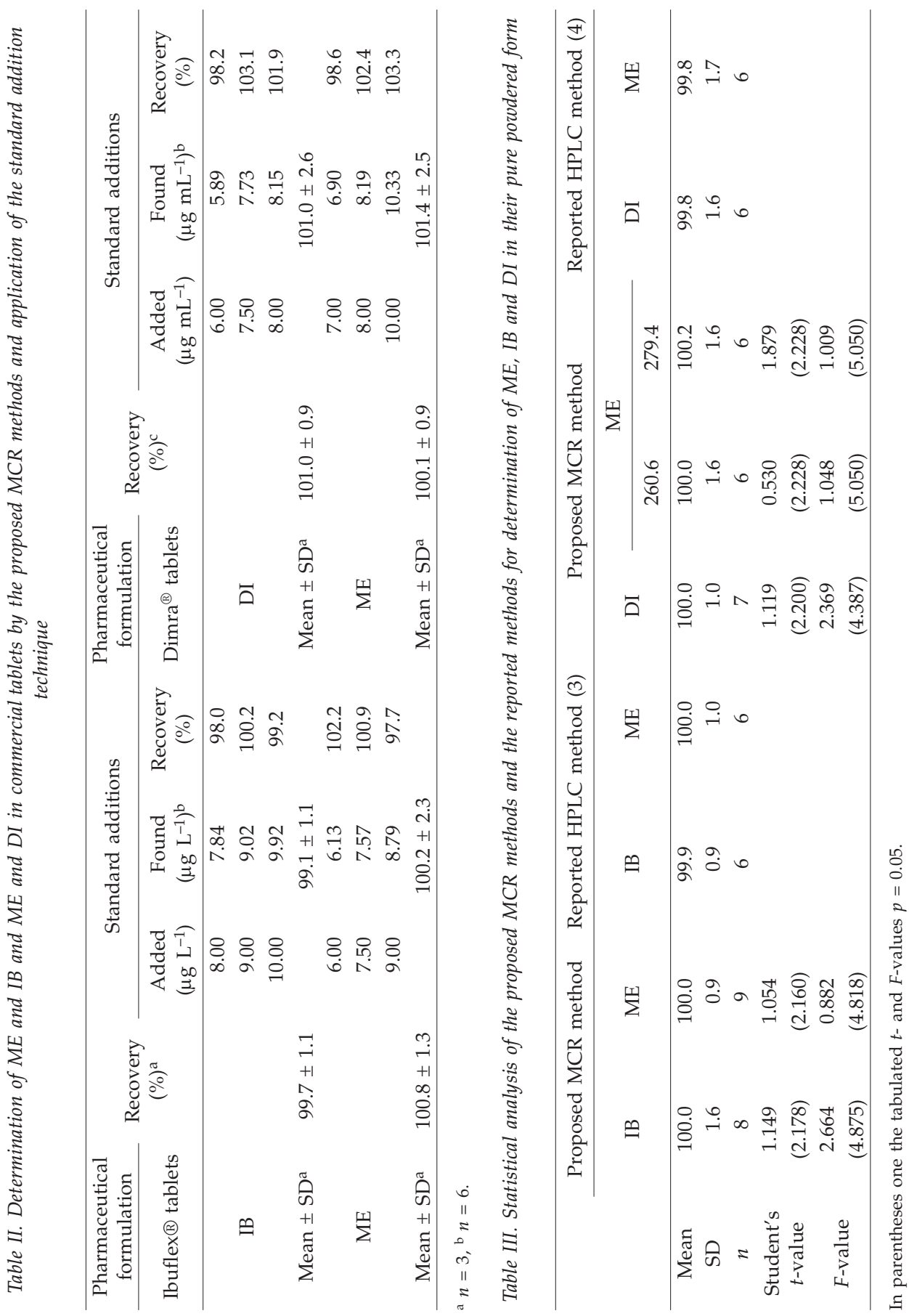
$\mathrm{mL}^{-1}, 3-12 \mu \mathrm{g} \mathrm{mL} \mathrm{m}^{-1}$ for ME and DI, respectively in the second mixture (Figs. 3a-d). The regression equations for the proposed methods were calculated and found to be:

$$
\begin{array}{ll}
Y_{1}=0.0825 \gamma_{1}-0.0612 & R_{1}=0.9999 \text { for ME at } 218.4 \mathrm{~nm}, \\
Y_{2}=0.0726 \gamma_{2}+0.0165 & R_{2}=0.9996 \text { for IB at } 218.4 \mathrm{~nm}, \\
Y_{3}=0.0463 \gamma_{3}-0.0104 & R_{3}=0.9997 \text { for ME at } 260.6 \mathrm{~nm}, \\
Y_{4}=0.0785 \gamma_{4}-0.0173 & R_{4}=0.9997 \text { for ME at } 279.4 \mathrm{~nm}, \\
Y_{5}=0.3412 \gamma_{5}+0.0548 & R_{5}=0.9997 \text { for DI at } 260.8 \mathrm{~nm}
\end{array}
$$

where, $Y_{1}$ and $Y_{2}$ are peak amplitudes at the selected wavelengths for ME and IB, respectively, while $Y_{3}, Y_{4}$ and $Y_{5}$ are peak amplitudes at the selected wavelengths for ME (two wavelengths) and DI, respectively; $\gamma_{1}$ and $\gamma_{2}$ are the concentrations in $\mu \mathrm{g} \mathrm{mL} \mathrm{m}^{-1}$ for ME and IB, respectively, while $\gamma_{3}, \gamma_{4}$ and $\gamma_{5}$ are the concentrations in $\mu \mathrm{g} \mathrm{mL}{ }^{-1}$ for ME (at
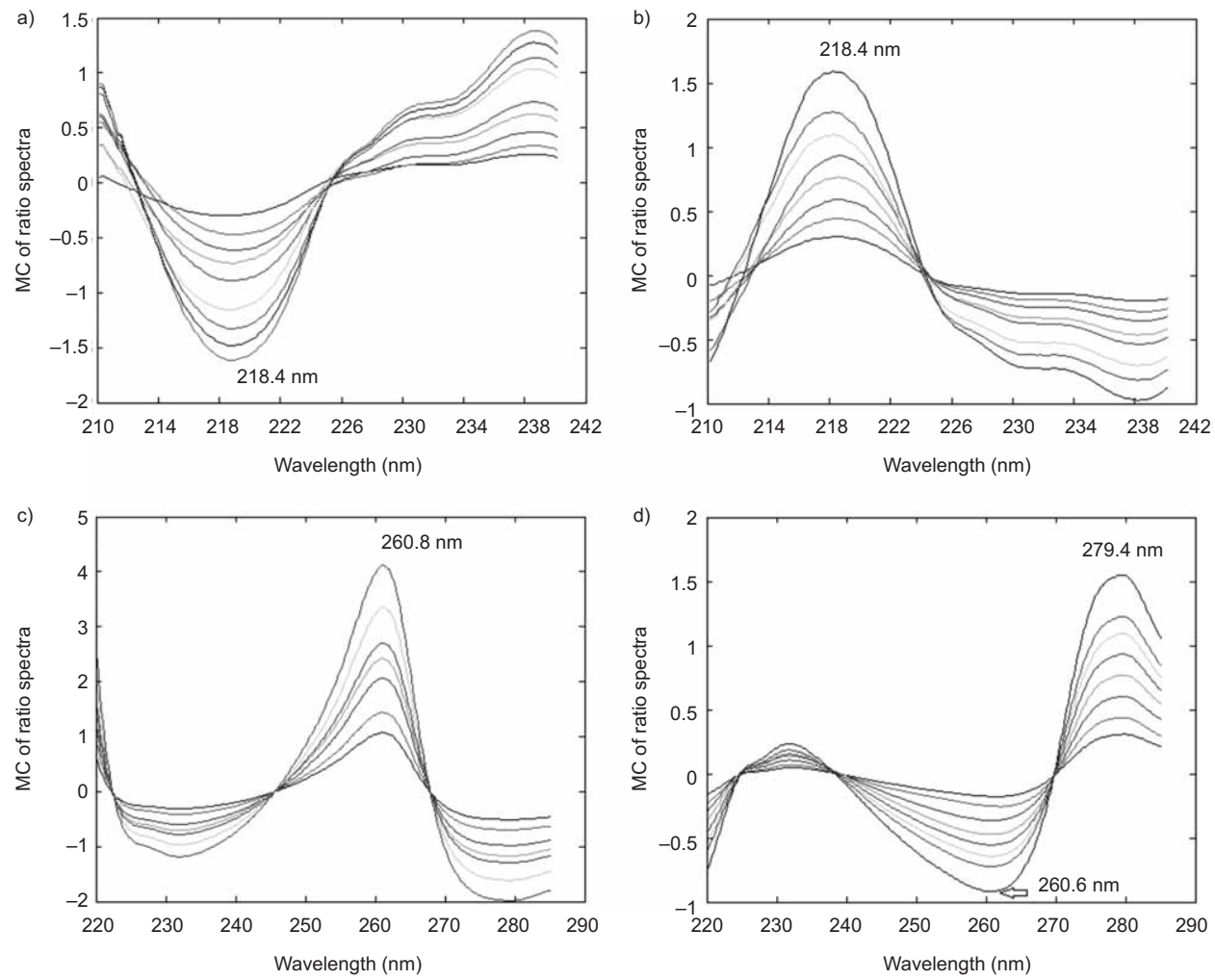

Fig. 3. The mean centered first ratio absorption spectra in $0.1 \mathrm{~mol} \mathrm{~L}^{-1} \mathrm{HCl}$ for: a) ibuprofen in the range $4-22 \mu \mathrm{g} \mathrm{mL}^{-1}$ using the spectrum of $4 \mu \mathrm{g} \mathrm{mL}^{-1} \mathrm{ME}$ as a divisor, b) methocarbamol in the range 4-20 $\mu \mathrm{g} \mathrm{mL}^{-1}$ using the spectrum of $4 \mu \mathrm{g} \mathrm{mL}^{-1} \mathrm{IB}$ as a divisor, c) diclofenac potassium in the range $3-12 \mu \mathrm{g} \mathrm{mL}^{-1}$ using the spectrum of $18 \mu \mathrm{g} \mathrm{mL}^{-1}$ of $\mathrm{ME}$ as a divisor, $\mathrm{d}$ ) methocarbamol in the range $4-20 \mu \mathrm{g} \mathrm{mL}-1$ using the spectrum of $6 \mu \mathrm{g} \mathrm{mL}-1$ of DI as a divisor. 
N. Wageih Ali et al:: Simultaneous determination of methocarbamol and ibuprofen or diclofenac potassium using mean centering of the ratio spectra method, Acta Pharm. 62 (2012) 191-200.

the corresponding wavelengths) and DI, respectively, whereas $R_{1}, R_{2}, R_{3}, R_{4}$ and $R_{5}$ are the respective correlation coefficients at the selected wavelengths. Good linearity is evident from the high value of the correlation coefficients (Table I).

Precision of the proposed methods is shown in Table I. Model accuracy of the proposed methods was checked by applying the proposed methods to determination of pure samples of the studied compounds and was found to be $100.0 \%$ for ME and IB and 100.0 and $100.2 \%$ for ME and DI, respectively. Concentrations were calculated from the corresponding regression equations and the results are shown in Table I. Accuracy was further assessed by applying the standard additions technique on Ibuflex ${ }^{\circledR}$ and Dimra ${ }^{\circledR}$ tablets where good recoveries were obtained, revealing no interference from excipients and good accuracy of the proposed methods (99.1 and $100.3 \%$ for IB and ME, respectively, and 101 and $100.1 \%$ for DI and ME, respectively, Table II).

Specificity of the proposed methods is evident from the spectra shown in Figs. 3a-d. Robustness of the proposed methods was evaluated in the development phase where the effect of different factors on mean centering of the ratio spectra methods was studied to obtain optimum parameters for complete separation (data not shown).

Table III shows statistical comparison of the results obtained by the proposed methods and the reported HPLC methods $(3,4)$. The calculated $t$ - and $F$-values are lower than the theoretical ones, indicating that there is no significant difference between the proposed methods and the reported method with respect to accuracy and precision.

\section{CONCLUSIONS}

The proposed methods are simple, selective and precise and could be easily applied for simultaneous determination of $\mathrm{ME}$ and $\mathrm{IB}$ or ME and $\mathrm{DI}$ in their binary mixtures.

\section{REFERENCES}

1. United States Pharmacopeia 30, National Formulary 25, USP Convention, Rockville (MD) 2007.

2. N. Pouli, A. Antoniadou-Vyzas and G. Foscolos, Methocarbamol degradation in aqueous solution, J. Pharm. Sci. 83 (1994) 499-501; DOI: 10.1002/jps.2600830411.

3. G. Subramanian, M. Vasudevan, S. Ravisankar and B. Suresh, Validation of a RP-LC method for simultaneous determination of paracetamol, methocarbamol and diclofenac potassium in tablets, Indian J. Pharm. Sci. 67 (2005) 260-263.

4. S. S. Zarapkar, U. P. Halkar and N. P. Bhandari, Reverse phase high performance liquid chromatographic determination of ibuprofen, paracetamol and methocatbamol in tablets, Indian Drugs 36 (1999) 710-713.

5. M. A. Rosasco, R. Ceresole, C. C. Forastieri and A. I. Segall, A stability indicating high-performance liquid chromatographic method for the determination of methocarbamol in veterinary preparations, J. AOAC Int. 92 (2009) 1602-1605; DOI: 10.5555/jaoi.92.5.1602.

6. A. Afkhami, T. Madrakian and L. Khalafi, Flow injection and batch spectrophotometric determination of ibuprofen based on its competitive complexation reaction with phenolphthalein $\beta$-cyclodextrin inclusion complex, Anal. Lett. 40 (2007) 2317-2328; DOI: 10.1080/00032710701575991. 
N. Wageih Ali et al.: Simultaneous determination of methocarbamol and ibuprofen or diclofenac potassium using mean centering of the ratio spectra method, Acta Pharm. 62 (2012) 191-200.

7. R. Leandro and T. Matthieu, Spectrophotometric determination of diclofenac in pharmaceutical preparations, J. Brazil. Chem. Soc. 16 (2005) 1068-1073; DOI: 10.1590/S0103-50532005000600026.

8. N. Erk, Y. Ozkan, E. Banoglu, S. A. Ozkan and Z. Senturk, Simultaneous determination of paracetamol and methocarbamol in tablets by ratio spectra derivative spectrophotometry and LC, J. Pharm. Biomed. Anal. 24 (2001) 469-475; DOI: 10.1016/S0731-7085(00)00447-7.

9. A. B. Thomas, N. G. Dumbre, R. K. Nanda, L. P. Kothapalli and A. A. Chaudhari, Simultaneous determination of tramadol and ibuprofen in pharmaceutical preparations by first order derivative spectrophotometric and LC methods, Chromatographia 68 (2008) 843-847; DOI: 10.1365/s10337$-008-0762-8$.

10. J. C. Duran-Alvarez, E. Becerril Bravo, V. S. Castro, B. Jimenez and R. Gibson, The analysis of a group of acidic pharmaceuticals, carbamazepine, and potential endocrine disrupting compounds in wastewater irrigated soils by gas chromatography-mass spectrometry, Talanta 78 (2009) 1159-1166; DOI: 10/1016/j.talanta.2009.01.035.

11. M. Walash, F. Belal, M. Eid and S. A. El Abass, Spectrofluorimetric determination of methocarbamol in pharmaceutical preparations and human plasma, J. Fluoresc. 21 (2011) 555-561; DOI: 10.1007/s10895-010-0742-x.

12. E. F. Elkady, Simultaneous spectrophotometric determination of diclofenac potassium and methocarbamol in binary mixture using chemometric techniques and artificial neural network, Drug Test. Anal. 3 (2011) 228-233; DOI: 10.1002/dta.216.

13. E. F. Elkady, Simultaneous determination of diclofenac potassium and methocarbamol in ternary mixture with guaifenesin by reversed phase liquid chromatography, Talanta 82 (2010) 1604-1607; DOI: 10.1016/j.talanta.2010.07.024.

14. A. Afkhami and M. Bahram, Mean centering of ratio spectra as a new spectrophotometric method for the analysis of binary and ternary mixtures, Talanta 66 (2005) 712-720; DOI: 10.1016/ j.talanta.2004.12.004.

15. International Conference on Harmonisation of Technical Requirements for Registration of Pharmaceuticals for Human Use, ICH Harmonized Tripartite Guideline, Validation of Analytical Procedures: Text and Methodology Q2(R1), Geneva 2005.

\title{
$S A \check{Z} E T A K$
}

\section{Simultano određivanje metokarbamola i ibuprofena ili diklofenak kalija metodom centriranja srednjih vrijednosti spektralnih omjera (mean centering of the ratio spectra method)}

\author{
NOURUDDIN WAGEIH ALI, MAHA AHAMD HEGAZY, \\ MOHAMED ABDELKAWY i EGLAL ABDELAHAMID ABDELALEEM
}

U radu su opisane točne i osjetljive metode za simultano određivanje metokarbamola i ibuprofena ili diklofenak kalija u njihovim binarnim smjesama, te $u$ prisutnosti gvajfenezina, supstancije srodne metokarbamolu koristeći metodu centriranja srednjih vrijednosti spektralnih omjera. Dobiveni rezultati su statistički uspoređeni s objavljenim HPLC metodama. Nije pronađena značajna razlika u točnosti i preciznosti između predložene metode i objavljenih metoda. 
N. Wageih Ali et al.: Simultaneous determination of methocarbamol and ibuprofen or diclofenac potassium using mean centering of the ratio spectra method, Acta Pharm. 62 (2012) 191-200.

Ključne riječi: metokarbamol, diklofenak kalij, ibuprofen, centriranje srednjih vrijednosti spektralnih omjera, gvajfenezin

Pharmaceutical Analytical Chemistry Department, Faculty of Pharmacy, Beni-Suef University, Beni-Suef, Egypt

Pharmaceutical Analytical Chemistry Department, Faculty of Pharmacy, Cairo University, Cairo, Egypt 